\title{
Analysis of Knowledge, Attitude and Motivation Towards Compliance of Pandemi Covid-19 Health Protocols in Community in Banter Village, Benjeng District, Gresik Regency
}

\author{
Kukuh Mujiono ${ }^{1}$, Katmini $^{2}$ \\ ${ }^{1}$ Akademi Refrasi Optesiin \\ Leprindo, Sidoarjo \\ ${ }^{2}$ Master Program of Public \\ Health, Institute of Health \\ Sciences Strada Indonesia, Kediri \\ Email: \\ kukuhmujiono@gmail.com
}

Received : October $4^{\text {nd }} 2021$

Accepted : October $15^{\text {rd }} 2021$

Published : November $27^{\text {th }} 2021$

\begin{abstract}
Coronaviruses are a large family of viruses that cause disease in humans and animals. The disease is mainly spread between people through respiratory droplets from coughs and sneezes. The design of this study is a quantitative analytic study with a cross sectional approach with the focus of the research being directed to analyze the influence of knowledge, attitudes and motivation on compliance with the Covid 19 pandemic health protocol in the community in Banter Village, Benjeng District, Gresik Regency. with a population of a number164 respondents and a sample of 116 respondents who were taken using the simple random sampling technique. Data analysis using Linear Regression test. Based on the results of the analysis multiple linear regression shows that with a p-value of $0.000<0.05, \mathrm{H} 1$ is accepted, so it can be concluded that simultaneously it exists the influence of knowledge, attitudes and motivation on compliance with the Covid 19 pandemic health protocol in the community in Banter Village, Benjeng District, Gresik Regency with a magnitude of $80.1 \%$.It is hoped that the community can comply with health protocols as appropriate which must use standard masks, maintain distance and be diligent in washing hands with soap. That way it can reduce the risk of spreading the Covid-19 virus.
\end{abstract}

Keywords: Covid-19, compliance, motivation, knowledge \& attitude

Copyright (C) 2021 IIK STRADA Indonesia All right reserved.

This is an open-acces article distributed under the terms of the Creative Commons AttributionShareAlike 4.0 International License.

\section{INTRODUCTION}

Coronaviruses are a large family of viruses that cause disease in humans and animals. In humans, it usually causes respiratory infections, from the common cold to serious illnesses such as Middle East Respiratory Syndrome (MERS) and Severe Acute Respiratory Syndrome (SARS). The disease is mainly spread between people through respiratory droplets from coughs and sneezes. This virus can last up to three days with plastic and stainless steel SARS CoV-2 can last up to three days, or in aerosols for three hours (Gorbalenya, 2020) This virus has also been found in feces, but until March 2020 it is not known whether transmission through the feces possible, and the risk is estimated to be low (Van Doremalen et al, 2020) 
On December 31, 2019, the WHO China Country Office reported a case of pneumonia of unknown etiology in Wuhan City, Hubei Province, China. On January 7, 2020, China identified pneumonia of unknown etiology as a new type of coronavirus (novel coronavirus). In early $2020 \mathrm{NCP}$ began to become a global pandemic and became a health problem in several countries outside the PRC. According to the World Health Organization (WHO), pneumonia cluster cases with unclear etiology in Wuhan City have become health problems around the world. The spread of this epidemic continued to grow until it was finally known that the cause of this pneumonia cluster was the Novel Coronavirus. This pandemic continues to grow until there are reports of deaths and new cases outside China. On January 30, 2020,

On February 12, 2020, WHO officially designated the novel coronavirus disease in humans as Coronavirus Disease (COVID-19). COVID-19 is caused by SARS-COV2 which belongs to the same large family of coronaviruses that caused SARS in 2003, only with a different type of virus. Symptoms are similar to SARS, but the SARS death rate (9.6\%) is higher than COVID-19 (currently less than 5\%), although the number of COVID-19 cases is far more than SARS. COVID-19 also has a wider and faster spread to several countries than SARS (Kemenkes RI, 2020).

Based on the results of a preliminary study conducted by researchers on September 25, 2020 at Banter Village, Benjeng District Gresik Regency to 10 respondents found that a number of 7 respondents $(70 \%)$ have low knowledge regarding covid-19 where the public thinks that the virus is just a government political game while the positive cases announced by the government are just lies so that people think the corona virus does not actually exist and the public does not care about which health protocol to wear masks, keep your distance or have to wash your hands frequently are also ignored by the community. Because of this, people do not have the motivation to want to follow health protocols properly. Meanwhile, a total of 30 respondents $(30 \%)$ claimed to be afraid of the corona virus and always obeyed to carry out health protocols.

A new type of corona virus that has been found in humans since an extraordinary incident appeared in Wuhan China, in December 2019, was then given the name Severe Acute Respiratory Syndrome Coronavirus 2 (SARS-COV2), and causes Coronavirus Disease-2019 ( COVID-19). COVID-19 belongs to the genus with fluorescence and is often pleomorphic in shape, and 60-140 nm in diameter. This virus is genetically very different from the SARS-CoV and MERS-CoV viruses. Current research shows that the homology between COVID-19 and the characteristics of the DNA of the coronavirus in bats-SARS is more than $85 \%$ similarity. When cultured in vitro, COVID-19 can be found in human respiratory epithelial cells after 96 hours. Meanwhile, to isolate and culture vero E6 and Huh-7 cell lines, it takes about 6 days (Kemenkes RI, 2020).

The lungs are the organs most affected by COVID-19, because the virus accesses host cells via the ACE2 enzyme, which is most abundant in alveolar type II cells of the lung. This virus uses special surface glycoproteins, called "spikes", to connect to ACE2 and enter host cells (Letko, 2020). ACE2 density in each network correlates with the severity of disease in that tissue and some experts argue that decreased ACE2 activity may be protective. And as alveolar disease progresses, respiratory failure may occur and death may occur (Xu H et al, 2020).

The high rate of spread of the corona virus is allegedly due to human factors, namely low knowledge of the virus and even the emergence of information related to conspiracies, besides that it is also due to the lack of public attitudes to comply with health protocols and people's motivation also tends to be low to use masks etc. as recommended by the officer in the health protocol. Where this is confirmed by the research conducted (Suppawittaya et al., 2020).

Lack of awareness in maintaining hand hygiene was indicated by $52.3 \%$ of participants not washing their hands before eating. Even though washing hands can reduce the risk of spreading the virus by as much as 55\% (Chen et al., 2020). In addition, washing hands is an activity that is easy to do and effective in reducing the risk of infection (Jamie, 2020). Then as many as $56.9 \%$ of participants did not carry hand sanitizers as a form of self-protection when outside the home. Even though hand sanitizers containing ethanol have virucidal activity (Kampf, 2018). So that by using a hand sanitizer, the process of microbial (virus) infection in humans can be prevented (Dewi et al., 2016).

Based on the above conditions, the authors are interested in researching the analysis of knowledge, attitudes and motivation towards compliance with the Covid 19 pandemic health protocol in the community in Banter Village, Benjeng District, Gresik Regency. 


\section{MATERIALS AND METHODS}

In this study, researchers used an observational quantitative design with a cross sectional approach, which is a study to study the dynamics of the correlation between risk factors and effects, by approaching, observing or collecting data at once (point time approach), that is, each subject. The study was only observed once and measurements were made of the character status or subject variables at the time of examination. This does not mean that all research subjects were observed at the same time (Soekidjo, 2012). This study will analyze the effect of knowledge, attitudes and motivation on compliance with the Covid 19 pandemic health protocol in the community in Banter Village, Benjeng District, Gresik Regency..

The total population of 164 respondents and a sample of 116 respondents who were taken by simple random sampling technique. Data analysis using Linear Regression test. With the number of Ethical Test Decree 2246/KEPK /1/2021.

\section{RESULTS}

Table 1 Results of linear regression analysis of knowledge, attitudes and motivation towards compliance with the Covid 19 pandemic health protocol in the community in Banter Village, Benjeng District, Gresik Regency which was held on 15-30 January 2021 with a total of 116 respondents

\begin{tabular}{cccccc}
\hline No. & Variable & Sig & B & $R^{2}$ & Sig \\
\hline 1 & (Constant) & 0.005 & 2,513 & & \\
\cline { 1 - 4 } 2 & Knowledge & 0.001 & 0.992 & 0.801 & \multirow{2}{*}{0.000} \\
\cline { 1 - 4 } 3 & Attitude & 0.001 & 0.680 & & \\
\cline { 1 - 5 } 4 & Motivation & 0,000 & 1,764 & & \\
\hline
\end{tabular}

\section{Partial}

a. The Influence of Knowledge on Compliance

Based on the results of Linear Regression analysis, it shows that the p-value is $0.001<0.05$, then $\mathrm{H} 1$ is accepted, so it is concluded that partially there is the influence of knowledge on compliance with the Covid 19 pandemic health protocol in the community in Banter Village, Benjeng District, Gresik Regency.

b. The Effect of Attitude on Compliance

Based on the results of Linear Regression analysis, it shows that the p-value is $0.001<0.05$, then $\mathrm{H} 0$ is rejected and $\mathrm{H} 1$ is accepted, so it is concluded that partially there is the influence of attitudes on compliance with the Covid 19 pandemic health protocol in the community in Banter Village, Benjeng District, Gresik Regency.

c. The Influence of Motivation on Compliance

Based on the results of Linear Regression analysis, it shows that the p-value is $0.029<0.05$, then $\mathrm{H} 0$ is rejected and $\mathrm{H} 1$ is accepted, so it is concluded that partially there is influence motivation for compliance with the Covid 19 pandemic health protocol in the community in Banter Village, Benjeng District, Gresik Regency

\section{Simultaneously}

Based on the results of the Multiple Linear Regression analysis, it shows that with a p-value of $0.000<0.05, \mathrm{H} 1$ is accepted so it can be concluded that simultaneously there is the influence of knowledge, attitudes and motivation on compliance with the Covid 19 pandemic health protocol in the community in Banter Village, Benjeng District, Gresik Regency with a magnitude of $80.1 \%$.

\section{DISCUSSION}

\section{A. Public Knowledge About the Covid 19 Pandemic Health Protocol in Banter Village, Benjeng District, Gresik Regency}

The results showed that almost half of the respondents had moderate category knowledge as many as 47 respondents (40.5\%). In addition, 42 respondents $(36.2 \%)$ had low category knowledge. Meanwhile, 23 respondents (23.3\%) had high category knowledge.

Knowledge is an impression in the human mind as a result of the use of his five senses.Knowledge is the result of human senses, or the result of a person's knowing of an object 
through their senses (eyes, nose, ears, etc.) (Notoatmodjo, 2013). According to Hendra (2013) knowledge is also influenced by information sources. Information can be obtained from various sources, namely the mass media, health workers as well as from friends and family.

The factors that influence knowledge are socioeconomic, culture (culture, religion), education, experience. Education is an effort to provide knowledge so that there is increased positive behavior change. The higher a person's knowledge, the better his behavior (Notoatmodjo, 2012).

Coronaviruses are a large family of viruses that cause disease in humans and animals. In humans it usually causes respiratory tract infections, from the common cold to serious illnesses such as Middle East Respiratory Syndrome (MERS) and Severe Acute Respiratory Syndrome (SARS). The disease is mainly spread between people through respiratory droplets from coughs and sneezes. This virus can last up to three days with plastic and stainless steel SARS CoV-2 can last up to three days, or in aerosols for three hours (Gorbalenya, 2020) This virus has also been found in feces, but until March 2020 it is not known whether transmission through the feces possible, and the risk is estimated to be low (Van Doremalen et al, 2020)

According to researchers, knowledge is the basis for someone to do something. If the knowledge is good, what will be done will be directed, whereas if the knowledge is lacking then what will be done tends to be unfocused. Based on the results of the study, it was found that many people who have knowledge of health protocols are still in the poor category, which can be seen from the wrong view of the community about Covid-19. The community considers that the health protocol does not need to be taken into account where when using the health protocol it actually makes it difficult for the community, especially in the economic sector. So that people tend to have inaccurate knowledge about Covid-19 and the existence of health protocols.

B. Community Attitudes About the Covid 19 Pandemic Health Protocol in Banter Village, Benjeng District, Gresik Regency

The results showed that almost half of the respondents had a moderate attitude as many as 47 respondents $(40.5 \%)$. In addition, a number of 41 respondents $(35.3 \%)$ had a poor attitude. Meanwhile, 28 respondents $(24.1 \%)$ had a good attitude.

An individual is very closely related to their respective attitudes as their personal characteristics. Attitude in general is often defined as an action taken by an individual to respond to something. The definition of attitude is explained by Saifudin Azwar (2010). Attitude is defined as a reaction or response that arises from an individual to an object which then raises the individual's behavior towards that object in certain ways.

Gerungan (2014) also describes the notion of attitude or attitude as a reaction to an individual's views or feelings towards certain objects. Even though the object is the same, not all individuals have the same attitude, it can be influenced by individual circumstances, experiences, information and different needs of each individual. A person's attitude towards objects will shape individual behavior towards objects.

Human attitudes are not formed since humans are born. Human attitudes are formed through social processes that occur during their lifetime, where individuals gain information and experience. This process can take place within the family, school and community. When a social process occurs, there is a reciprocal relationship between the individual and his surroundings. The existence of these interactions and relationships then forms a pattern of individual attitudes with their surroundings. Saifudin Azwar (2010) describes the factors forming attitudes, namely: strong experiences, the influence of others who are considered important, the influence of culture, mass media, educational institutions and religious institutions, the influence of emotional factors.

Attitude is the response of someone who is still closed to a stimulus or object. Manifestation of that attitude cannot be immediately seen, but can only be interpreted first from closed behavior. Attitudes will be more easily formed when personal experiences occur in situations that involve emotional factors. Based on the results of the study, it was found that most of the respondents had a fairly good attitude, but there were still many respondents who had less attitudes. The lack of respondent attitudes is due to the lack of understanding of the public's view of the Covid-19 virus outbreak and the function of carrying out health protocols. Because of this misunderstanding, people prefer to ignore everything related to health protocols. 


\section{Motivation to Follow the Covid 19 Pandemic Health Protocol in Communities in Banter Village, Benjeng District, Gresik Regency}

The results showed that almost half of the respondents had moderate motivation as many as 48 respondents (41.4\%). In addition, a number of 40 respondents $(34.5 \%)$ have motivation in the low category. Meanwhile, a total of 28 respondents (24.1\%) have high motivation.

Motivation is what causes and supports a person. According to Mashlow (2014) in Sunaryo (2013), individuals will be motivated to fulfill what needs are strongest in themselves at a certain moment. If it is said that the emergence of a person's behavior at a certain time is determined by a need that has high strength.

Motivation is what causes and supports a person. According to Sunaryo (2013), individuals will be motivated to fulfill what needs are strongest in themselves at a certain moment. If it is said that the emergence of a person's behavior at a certain time is determined by a need that has high strength, it is important for every manager to have knowledge of the needs that are felt to be most important to their subordinates.

According to Ngalim Purwanto (2000) motivation is anything that encourages someone to do something. Motivation is to provide a stimulus or impetus or an excitement to a person or group so that they want to work properly and energetically. With the ability he has to achieve goals in an efficient and efficient manner (Wijono D, 2012).

According to Sunarya in the psychology book for nursing (2013), motivation is the desire and need of an individual, to motivate the individual to meet their needs and direct their directed behavior towards everything they aim at. According to Nancy Stevenson (2011) motivation is all verbal, physical, or psychological things that make someone do something in response. And according to Suwarno, sw (2010) motivation refers to the process of movement, including situations that encourage arising from within the individual, behavior brought about by the situation and the ultimate goal of the movement or deed.

Motivation is the basis for someone willing to do an activity. Motivation will encourage someone to do something. Motivation will provide a stimulus or impetus or an excitement to a person or group to want to do something properly and energetically. With the ability he has to achieve goals in an efficient and efficient manner. Motivation itself will refer to the process of movement, including encouraging situations that arise from within the individual, the behavior caused by these situations and the ultimate goal of the movement or action.

According to researchers, motivation will encourage someone to do something, where if someone has high motivation then that person will do everything he can to achieve his wishes. Based on the results of the study, it was found that most of the respondents had a high enough motivation category, but it was found that there were still many who had low motivation. Where this is due to the perspective of the community itself, where the community thinks that health protocols are unnecessary and instead complicates the community's economy.

\section{Covid 19 Pandemic Health Protocol Compliance with Communities in Banter Village, Benjeng District, Gresik Regency}

The results showed that most respondents did not comply with the health protocol as many as 85 respondents $(73.3 \%)$. Meanwhile, 31 respondents $(36.7 \%)$ complied with the health protocol.

Compliance or obedience (compliance / adherence) is the level of a person carrying out activities and behaviors that have been suggested or determined (Konis, 2012). Compliance is a term to describe obedience or surrender to predetermined goals.

Wesker (2014) argues that the factors that affect the level of compliance are anything that can have a positive effect so that the sufferer is no longer able to maintain adherence, until he becomes less obedient and disobedient.

No one follows instructions if he misunderstands the instructions given to him. Sometimes this is due to a professional failure to provide complete information and to provide a lot of instructions that a person should remember. The level of education can increase compliance, as long as it is an active education that is obtained independently, through certain 
stages. Suparyanto (2010) states that the older a person is, the better his mental development process, but at certain ages, the increase in mental development processes is not as fast as when he was a teenager. Thus it can be concluded that the age factor will affect a person's level of knowledge which will peak at certain ages and will decrease the ability to accept or remember something as age gets older. This is supported by a low level of education.

The personalities between people who are obedient and those who fail are different. A person who is disobedient is a person who is depressed, has anxiety, is very concerned about his health, has weaker ego power and has a more social life, is focused on himself. The power of the ego is more marked by a lack of control over the environment. Demographic variables are also used to predict non-compliance (Wilujeng, 2015).

According to researchers, compliance is the level of a person carrying out activities and behaviors that have been suggested or defined. Compliance is a term to describe obedience or surrender to predetermined goals. Likewise in the community, most people do not obey when given instructions by the government or related agencies because people easily accept all negative information rather than positive information, so news that is not true is very easy to spread in the community and people believe it. So that the result of the large amount of goax information causes people to tend to ignore and not comply with the health protocol instructions from the government.

E. The Influence of Knowledge on Compliance with Covid 19 Pandemic Health Protocols in Communities in Banter Village, Benjeng District, Gresik Regency

Based on the results of Linear Regression analysis, it shows that the p-value is 0.001 $<0.05$, then $\mathrm{H} 1$ is accepted, so it is concluded that partially there is the influence of knowledge on compliance with the Covid 19 pandemic health protocol in the community in Banter Village, Benjeng District, Gresik Regency.

In today's world, Covid-19 is a pandemic case since March 11, 2020. Covid-19 is a disease caused by the corona virus. Coronaviruses $(\mathrm{CoV})$ are part of the virus family that causes illnesses ranging from the flu to more severe illnesses such as Middle East Respiratory Syndrome (MERS-CoV) and Severe Acute Respiratory Syndrome (SARS-CoV). The disease caused by the corona virus, otherwise known as COVID-19, is a new type that was discovered in 2019 and has never been identified as attacking humans before (Widiyani, 2020).

The corona virus case appeared and attacked humans for the first time in Wuhan province, China. Early appearance is thought to be pneumonia, with symptoms similar to flu in general. These symptoms include coughing, fever, fatigue, shortness of breath, and no appetite. However, unlike influenza, the corona virus can develop rapidly, resulting in more severe infections and organ failure and death. This emergency condition mainly occurs in patients with previous health problems (Mona, 2020).

Compliance is a term used to describe people's behavior in wearing masks. Compliance is positive behavior shown by society when people use masks. Factors that affect compliance depend on many factors, including knowledge, motivation, attitudes, and beliefs in disease control and prevention efforts, environmental variables, quality of health instructions, and ability to access existing resources (Sinuraya et al., 2018). Meanwhile, non-compliance is a condition when an individual or group wishes to comply, but there are a number of factors that hinder adherence to health advice given by health workers (Prihantana et al, 2016).

According to researchers, compliance goes straight with how high a person knows the dangers of Covid-19. When someone tends to have high knowledge, he will be more obedient to carrying out health protocols and vice versa when someone doesn't know much about Covid-19 and even has wrong knowledge, he will tend to not comply with health protocols. So it can be concluded that there is an influence of knowledge on compliance with the Covid 19 pandemic health protocol in the community in Banter Village, Benjeng District, Gresik Regency.

F. The Influence of Attitudes Toward Compliance with Covid 19 Pandemic Health Protocols in Communities in Banter Village, Benjeng District, Gresik Regency

Based on the results of Linear Regression analysis, it shows that the p-value is 0.001 $<0.05$, then $\mathrm{H} 0$ is rejected and $\mathrm{H} 1$ is accepted, so it is concluded that partially there is the influence of attitudes on compliance with the Covid 19 pandemic health protocol in the community in Banter Village, Benjeng District, Gresik Regency. 
Corona virus is a new type of virus that has now shocked the world community (Mona, 2020). The problem is this virus has managed to infect thousands of millions of people globally in a very short time ( $\mathrm{Li}$ et al., 2020). Even humans without showing symptoms of being infected with the Corona virus can also spread it to other humans (Kumar \& Dwivedi, 2020).

Anticipating an increase in the spread and number of infections, the public is encouraged to adopt a new healthy lifestyle according to health protocols during the Corona virus pandemic. One form of this health protocol is to maintain cleanliness and not to have direct contact with patients who are positive for Corona virus (Izzaty, 2020). Then, use a face mask when traveling or outside the home (Howard et al., 2020). Furthermore, maintaining hygiene by washing hands or using a handsanitizer (Lee et al., 2020). The last is the application of social distancing by keeping a distance of 1 meter and covering the mouth when coughing or sneezing using the arm (Hafeez et al., 2020).

Coronavirus is a collection of viruses that can infect the respiratory system. In most cases, this virus causes only mild respiratory infections, like the flu. However, this virus can also cause serious respiratory infections, such as lung infections / pneumonia. (Dr. Merry Dame Cristy Pane 2020). As a result of this pandemic, anxiety arose from all people including residents at the Hanudnas Education and Training Center. One of the factors arising anxiety from the community is because they do not know whether the people around them are healthy or not so they also avoid crowds or gatherings that invite large numbers of people. And they fear themselves whether they are bringing the virus to those around them. This is due to the lack of information and fake news about COVID-19 which likes to circulate carelessly.

Since the COVID-19 pandemic, many major changes have occurred in various aspects of our lives. One of the most felt is the must to applyphysical distancingand reduce travel outside the home when there is no urgent need to break the chain of transmissionCorona virus. Faced with this new, arguably unpleasant rule, can cause confusion and anxiety for the general public and the extended family of the Hanudnas Education and Training Center in particular, especially if it is not explained why this new rule happened suddenly without any partialization, as a result they can interpret the outside world and strangers as something scary and will have a negative impact on his mental health. SThe stress and anxiety caused by a pandemic can impact physical and mental health (Dr. Bruce Schwartz).

G. Motivation Towards Compliance with the Covid 19 Pandemic Health Protocol in Communities in Banter Village, Benjeng District, Gresik Regency

Based on the results of Linear Regression analysis, it shows that the p-value is 0.029 $<0.05$, then $\mathrm{HO}$ is rejected and $\mathrm{H} 1$ is accepted, so it is concluded that partially there is influence motivation for compliance with the Covid 19 pandemic health protocol in the community in Banter Village, Benjeng District, Gresik Regency

The application of the health protocol serves as a prevention for the spread of Corona virus infection to the wider community. Some examples of health protocols that have been issued by the Indonesian government during the Corona virus pandemic are: a) Using a mask; b) Covering the mouth when coughing and sneezing in the crowd; c) Adequate rest if the body temperature is $38^{\circ} \mathrm{C}$ or more and coughs and colds; d) Prohibition of using public transportation for people who are sick; e) If there are people who meet the criteria for suspicion, they will be referred to a Covid hospital or conduct isolation (Presidential Staff Office, 2020).

Face protective masks are a form of self-protection during the Corona virus pandemic. This statement has also been strengthened by the World Health Organization (WHO) through temporary guidelines announced on April 6, 2020 regarding the recommendation to increase masks (World Health Organization, 2020b). Face protective masks are very important to use because they not only function as protection, but also prevent the spread of Corona virus infection (Shen et al., 2020). Through the use of face masks, the spread of the Corona virus can also be controlled (Cheng et al., 2020).

Maintaining personal hygiene during the Corona virus pandemic such as washing hands is one of the steps that people need to take. The World Health Organization (WHO) has also explained that maintaining hand hygiene has been able to save human lives from Corona virus infection (World Health Organization, 2020d). However, washing hands cannot be done carelessly by the community. Washing hands properly in 20 seconds or more using running water 
and liquid soap is an effective method that is recommended and really needs to be applied by the community (Khedmat, 2020). Through the act of washing hands, the transmission cycle and the risk of spreading the Corona virus between $6 \%$ and $44 \%$ can be reduced (Chen et al., 2020).

Although social distancing is one of the policies that are now being implemented by the world community during the Corona virus pandemic. During the implementation of the social distancing policy, the Indonesian government has implemented several activities such as: a) Studying and working from home; b) Stay at home; c) Prohibit activities and; d) Limiting operating hours in public places (Yanti et al., 2020). The purpose of social distancing or physical distancing activities is to minimize interactions between communities where there may be some residents being infected but not doing self-isolation (Suppawittaya et al., 2020). In addition, social distancing activities also have a significant impact in minimizing the crime rate due to the economic crisis during the Corona virus pandemic (Ippolito et al., 2020).

The spread of the Corona virus in the world has taken place quickly with millions of infected patients. One of the processes of spread can be through direct contact inhalation with droplet droplets of infected patients (Singhal, 2020). The problem that is now emerging is that there are infected patients who show no symptoms so that the process of spreading the Corona virus is difficult to identify (Nishiura et al., 2020).

\section{CONCLUSION}

1. Nearly half of the respondents have moderate category knowledge as many as 47 respondents $(40.5 \%)$.

2. Nearly half of the respondents 47 respondents $(40.5 \%)$ had sufficiently categorized attitude.

3. Almost half of the respondents have medium category motivation as many as 48 respondents $(41.4 \%)$.

4. Most of the respondents 85 respondents (73.3\%) did not comply with the health protocol.

5. There is the influence of knowledge on compliance with the Covid 19 pandemic health protocol in the community in Banter Village, Benjeng District, Gresik Regency

6. There is the influence of attitudes on compliance with the Covid 19 pandemic health protocol in the community in Banter Village, Benjeng District, Gresik Regency

7. There is influence motivation for compliance with the Covid 19 pandemic health protocol in the community in Banter Village, Benjeng District, Gresik Regency

\section{SUGGESTION}

1. For Respondents

It is hoped that the community can comply with health protocols as appropriate which must use standard masks, maintain distance and be diligent in washing hands with soap. That way it can reduce the risk of spreading the Covid-19 virus.

2. For Educational Institutions

It is hoped that educational institutions can use the results of this study as input for learning in the analysis of knowledge, attitudes and motivation for compliance with the Covid 19 pandemic health protocol in the community in Banter Village, Benjeng District, Gresik Regency and can be developed again for further research to make it more useful for readers and researchers.

3. For Further Researchers

It is hoped that further research needs to be deepened and added with more specific research factors that affect the motivation of the community in implementing the Covid 19 pandemic health protocol in the community in Banter Village, Benjeng District, Gresik Regency

4. For Puskesmas

It is hoped that the health center can use the results of this research as input for learning to increase knowledge, attitudes and motivation towards compliance with the Covid 19 pandemic health protocol in the community in Banter Village, Benjeng District, Gresik Regency. 


\section{ACKNOWLEDGMENT}

I state truthfully that to the best of my knowledge, in this thesis manuscript there is no scientific work that has been submitted by other people to obtain an academic degree in a university, and there are no works or opinions that have been written or put in order by people. other, except those quoted in writing in this text and mentioned in the sources of citations and bibliography.

\section{CONFLICT OF INTEREST}

In this research, there is no interest whatsoever related to my self or with other institutions apart from the Strada Indonesia Institute of Health Sciences, Kediri City.

\section{REFERENCES}

Azwar Ali, S., Baloch, M., Ahmed, N., Arshad Ali, A., \& Iqbal, A. (2020). The outbreak of Coronavirus Disease 2019 (COVID-19) - An emerging global health threat. Journal of Infection and Public Health, 13(4), 644-646. https://doi.org/10.1016/j.jiph.2020.02.0 33

Dewi, Ika; Raharyani, A. E. (2020). Tingkat Pengetahuan Dan Perilaku Masyarakat Kabupaten Wonosobo Tentang Covid-19. Jurnal Ilmiah Kesehatan, 10(1), 33-42. Retrieved from https://ojs.unsiq.ac.id/index.php/jik/artic le/view/1311/783

Gorbalenya Guan, W., Ni, Z., Hu, Y., Liang, W., Ou, C., He, J., ... Zhong, N. (2020). Clinical characteristics of coronavirus disease 2019 in China. New England Journal of Medicine, 382(18), 1708-1720. https://doi.org/10.1056/NEJMoa200203 2

Hendra, Aslam, F. (2020). COVID-19 and Importance of Social Distancing. Preprints, 30(1), 1-6. https://doi.org/10.20944/preprints20200 4.0078.v1

Kemenkes RI. (2020). Tanya jawab seputar virus corona. Jakarta: Kementerian Kesehatan Republik Indonesia.

Notoatmodjo (2014). Pengembangan Sumber Daya Manusia. Jakarta : PT. Rineke Cipta

Soekidjo. (2012). Konsep Penerapan Metode Penelitian Ilmu Keperawatan. Jakarta: Salemba Medika.

Sunaryo J. (2013) Beban Ganda Masalah Gizi dan Implikasinya terhadap Kebijakan Pembangunan Kesehatan Nasional. Penelitian Universitas Gajah Mada. Yogyakarta

Suparyanto, F. (2018). Penerapan Perilaku Hidup Bersih Dan Sehat (Phbs) Demi Kesejahteraan Masyarakat Kecamatan Tuntang Kabupaten Semarang Jawa Tengah. Jurnal Pemberdayaan: Publikasi Hasil Pengabdian Kepada Masyarakat, 1(1), 13. https://doi.org/10.12928/jp.v1i1.309

Suppawittaya, P., Yiemphat, P., \& Yasri, P. (2020). Effects of Social Distancing, Self-Quarantine and Self-Isolation during the COVID-19 Pandemic on People's Well -Being, and How to Cope with It. International Journal of Science and Healthcare Research, 5(2), 12-20.

Van Doremalen, N., Bushmaker, T., Morris, D. H., Holbrook, M. G., Gamble, A., Wiliamson, B. N., ... Munster, V. J. (2020). Aerosol and Surface Stability of SARS-CoV-2 as Compared with SARSCoV-1. Nejm, 382(1), 1564-1567.

Widiyani, Utami, R. A., Mose, R. E., \& Martini, M. (2020). Pengetahuan, Sikap dan Keterampilan Masyarakat dalam Pencegahan COVID-19 di DKI Jakarta. Jurnal Kesehatan Holistic, 4(2), 6877. https://doi.org/10.33377/jkh.v4i2.85

Wijono Dramantyo (2012) Manajemen Puskesmas Berbasis Paradigma Sehat. Jakarta : Penerbit CV Sagung Seto

Xu, Z., \& McGoogan, J. M. (2020). Characteristics of and Important Lessons from the Coronavirus Disease 2019 (COVID-19) Outbreak in China: Summary of a Report of 72314 Cases from the Chinese Center for Disease Control and Prevention. JAMA - Journal of the American Medical Association, 323(13), 1239-1242. https://doi.org/10.1001/jama.2020.2648 